\title{
Dural Carotico-Cavernous Fistula: Pre and Postembolization Appearances of Bone-Subtracted CT Angiography
}

\author{
Dural Karotiko-Kavernöz Fistülïn Kemik Baskılı Bilgisayarl Tomografi \\ Anjiyografi ile Pre ve Postembolizasyon Görünümleri
}

Osman KOC ${ }^{1}$, Emine GENC $^{2}$, Banu OZTURK ${ }^{3}$, Bulent Oguz GENC ${ }^{2}$, Fatıh KESKIN ${ }^{4}$, Orhan OZBEK

${ }^{1}$ Selcuk University, Meram Faculty of Medicine, Department of Radiology, Konya, Turkey

${ }^{2}$ Selcuk University, Meram Faculty of Medicine, Department of Neurology, Konya, Turkey

${ }^{3}$ Selcuk University, Meram Faculty of Medicine, Department of Ophtalmology, Konya, Turkey

${ }^{4}$ Selcuk University, Meram Faculty of Medicine, Department of Neurosurgery, Konya, Turkey

Correspondence address: Osman KOC / E-mail: drosmankoc@yahoo.com

\begin{abstract}
Digital subtraction angiography (DSA) is the best method of evaluating carotid cavernous fistulas (CCF). DSA, however, has the disadvantage of being an invasive procedure. Computerized tomography (CT) angiography which is noninvasive, have been shown to provide more information about the size and location of fistulas. As a new method, Bone-Subtraction CT Angiography (BSCTA), than conventional CT angiography, is a method that improves the detection and interpretation of vascular lesions near to the cavernous segment of carotid artery. In this case report, we report a case of a dural carotico-cavernous fistula (CCF), appearances of pre and postembolization BSCTA images, confirmed by on DSA. As far as we know, CCF demonstrated by BSCTA has not been reported yet.
\end{abstract}

KEYWORDS: Computed tomography angiography, Embolization, Carotico-cavernous fistula

öz

Dijital subtraksiyon anjiyografi (DSA) karotiko-kavernöz fistülü (KKF) değerlendirmede en iyi metodtur. Ancak DSA invaziv bir yöntemdir. Noninvaziv bir yöntem olan Bilgisayarlı tomografi (BT) anjiyografi fistül lokalizasyonu ve büyüklüğünü gösterebilir. Yeni bir yöntem olan Kemik baskılı BT anjiyografi (KBBTA) özellikle karotid arterin kavernöz segment lezyonlarının saptanmasında ve yorumlanmasında konvansiyonel BT anjiyografiye göre daha değerli bilgiler vermektedir. Bu olgu sunumunda, tanısı DSA ile doğrulanmış KKF olgusunun pre ve postembolizasyon görüntülerini sunduk. Bizim bilgilerimize göre KBBTA ile tanısı konulan KKF olgusu bildirilmemiştir.

ANAHTAR SÖZCÜKLER: Bilgisayarlı tomografi anjiyografi, Embolizasyon, Karotiko-kavernöz fistül

\section{INTRODUCTION}

Digital subtraction angiography (DSA) is the best method of evaluating carotid cavernous fistulas (CCF) before treatment by using an embolization procedure or surgery (3). DSA, however, has the disadvantage of being an invasive procedure. Alternatively, source images of CT angiography (CTA) have been shown to provide more information about the size and location of fistulas (3). Bone-Subtraction CT Angiography (BSCTA) is a fast and stable method that improves the detection and interpretation of vascular lesions near to the skull base and cavernous segment of carotid artery (10).

\section{CASE REPORT}

A 79-year-old woman was referred to progressive exophthalmos and ptosis of the right eye with a 2-mounth history. She described right retro-orbital pain, diplopia, dizziness and vomiting. There was a history of hypertension and diabethes mellitus but no history of trauma. On examination, she had a right sixth nerve palsy, chemosis and non-pulsatile exophthalmos of the right eye globe. BSCTA was performed with a 64-slice CT scanner (Siemens, Somatom Sensation 64). Axial images were reconstructed and then sent to a workstation. Bone subtraction was performed automatically without any user interaction. BSCTA showed dilatation of the right superior orbital vein and facial vein (Figure 1A). Digital subtraction angiography (DSA) confirmed the dural right CCF, fed by the external carotid artery and the meningohypophyseal trunk of the internal carotid artery (Figure 2A). With inferior petrosal sinus approach, transvenous embolization of the right cavernous sinus and proximal superior ophthalmic vein (SOV) by detachable coils was performed. The ocular symptoms of the patient were improved after the operation. Postembolization angiography (Figure 2B) and BSCTA after 3-days (Figure 1B) showed total occlusion of the fistula. 

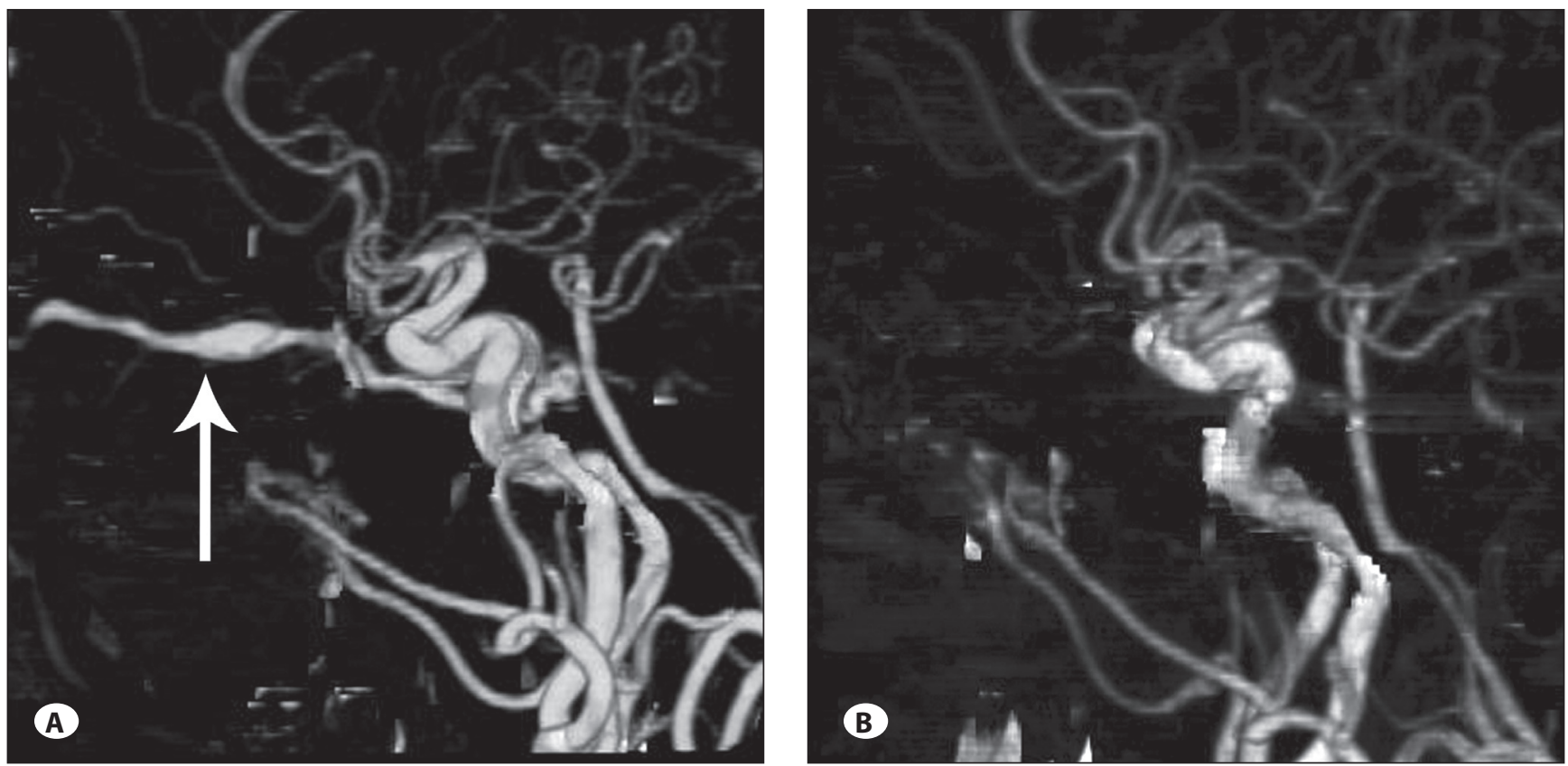

Figure 1: BSCTA volume rendering images. (A) Preembolization image shows dilated superior ophthalmic vein (arrow), (B) Postembolization 6-month control image shows the occluded fistula.

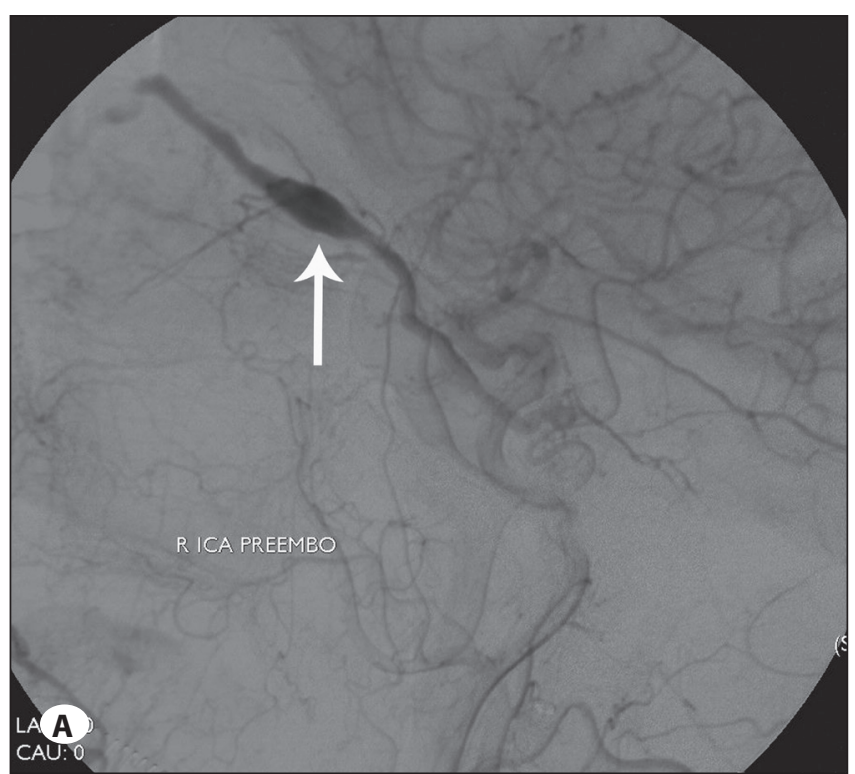

Figure 2: (A) Preembolization angiography shows right CCF and (B) Postembolization angiography reveals total occlusion of the fistula with multiple detachable microcoils.

\section{DISCUSSION}

CCF are classified as direct fistulas, which are often posttraumatic high-flow shunts between the cavernous portion of the internal carotid artery and the cavernous sinus, or indirect/dural fistula. Dural CCF are mostly abnormal communications between the dural branches of the internal and/or external carotid artery, the vertebral arteries, and the cavernous sinus (7). Dural CCF present most commonly in elderly women. Reversed blood flow in the SOV will result in various ophthalmic symptoms such as proptosis, chemosis,

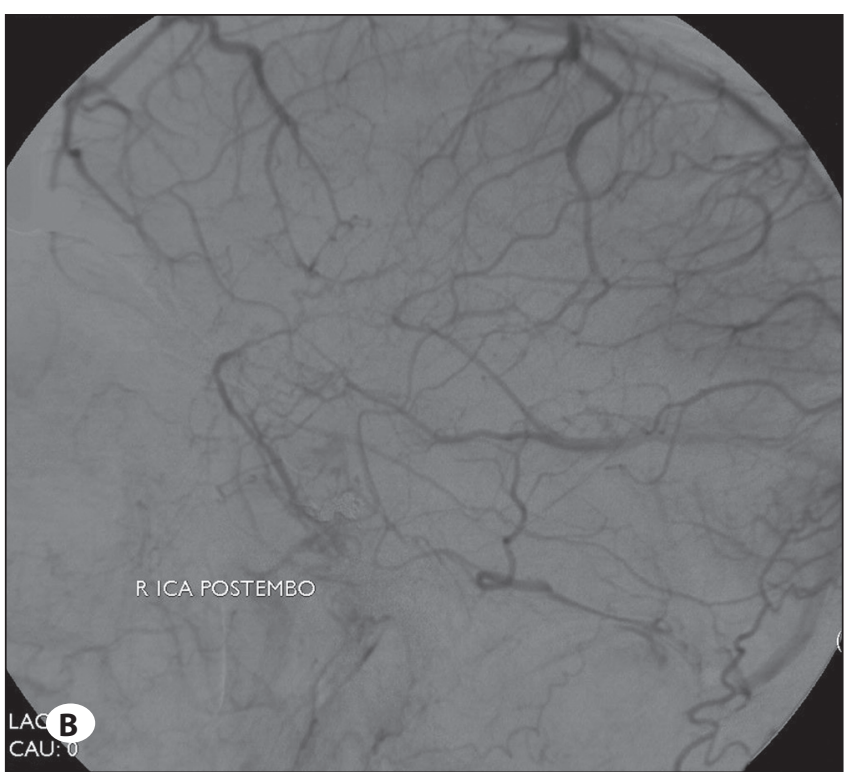

retroorbital pain, diminished visual acuity, and cranial nerves palsies (III, IV, V, and VI; partial or complete) $(4,6)$.

Dural CCF can be treated by transarterial (1-4) and/or transvenous $(5-9,11)$ endovascular techniques. The venous route goes usually through the internal jugular vein and the inferior petrosal sinus up to the pathologic shunts of the cavernous sinus $(5-9,11,12)$.

DSA is the best diagnostic modality for the detection of intracranial aneurysms and other vascular malformations. CTA 
is increasingly applied for detection and therapy planning of intracranial aneurysms. (12) In contrast to DSA, some vessel segments, such as cavernous portion of the internal carotid artery, cavernous sinus and superior ophtalmic vein, are not assessable on CTA because they course behind or through bone (4). CTA seems to be a reliable first-line diagnostic tool in evaluating the presence of a CCF in a suggestive clinical context, and to offer an accurate and safe method for noninvasive and reproducible follow-up. BSCTA, a technique that creates a bone mask from a nonenhanced CT scan, which is then subtracted from the CTA data, is the better visualizations of this vessels than nonsubtracted CTA. As far as we know, CCF demonstrated by BSCTA has not been reported yet.

\section{REFERENCES}

1. Anderson K, Collie DA, Capewell A: CT angiographic appearances of carotico-cavernous fistula. Clin Radiol 56: 514-516, 2001

2. Biondi A, Milea D, Cognard C, Ricciardi GK, Bonneville F, van Effenterre R: Cavernous sinus dural fistulae treated by transvenous approach through the facial vein: Report of seven cases and review of the literature. Am J Neuroradiol 24:1240-1246, 2003

3. Chen CC, Chang PC, Shy CG, Chen WS, Hung HC: Angiography and MR Angiography inthe evaluation of carotid cavernous sinus fistula prior to embolization: A comparison of Techniques. Am J Neuroradiol 26:2349-2356, 2005

4. Coskun $O$, Hamon $M$, Catroux G, Gosme L, Courthéoux $P$, Théron J: Carotid-cavernous fistulas: Diagnosis with spiral CT angiography. Am J Neuroradiol 21:712-716, 2000
5. He HW, Jiang CH, Wu ZX, Li YX, Wang ZC: Transvenous embolization of cavernous dural arteriovenous fistula: Report of 28 cases. Chinese Medical Journal 120:2229-2232, 2007

6. Kirsch M, Henkes H, Liebig T, Weber W, Esser J, Golik S, Kühne D: Endovascular management of dural carotid-cavernous sinus fistulas in 141 patients. Neuroradiology 48:486-490, 2006

7. Klisch J, Huppertz HJ, Spetzger U, Hetzel A, Seeger W, Schumacher M: Transvenous treatment of carotid cavernous and dural arteriovenous fistulae: Results for 31 patients and review of the literature. Neurosurgery 53:836-856, 2003

8. Li Q, Lv F, Li Y, Li K, Luo T, Xie P: Subtraction CT angiography for evaluation of intracranial aneurysms: Comparison with conventional CT angiography. Eur Radiol 19:2261-2267, 2009

9. Lell MM, Kramer M, Klotz E, Villablanca P, Ruehm SG: Carotid computed tomography angiography with automated bone suppression: A comparative study between dual energy and bone subtraction techniques. Invest Radiol 44:322-328, 2009

10. Morhard D, Fink C, Becker C, Reiser MF, Nikolaou K: Value of automatic bone subtraction in cranial CT angiography: Comparison of bone-subtracted vs. standard CT angiography in 100 patients. Eur Radiol 18: 974-982, 2008

11. Romijn M, Gratama van Andel HA, van Walderveen MA, Sprengers ME, van Rijn JC, van Rooij WJ, Venema HW, Grimbergen CA, den Heeten GJ, Majoie CB: Diagnostic accuracy of CT angiography with matched mask bone elimination for detection of intracranial aneurysms: Comparison with digital subtraction angiography and 3D rotational angiography. Am J Neuroradiol 29:134-139, 2008

12. Tomandl BF, Hammen T, Klotz E, Ditt H, Stemper B, Lell M: Bone-subtraction CT angiography for the evaluation of intracranial aneurysms. Am J Neuroradiol 27:55-59, 2006 